\title{
In Vitro Screening Ketahanan Galur Padi (Oryza sativa) B7 Hasil Rakitan Politeknik Negeri Lampung Terhadap Keracunan Unsur Besi $(\boldsymbol{F e})$
}

\section{In Vitro Screening Of B7 Paddy (Oryza sativa) Strain For Iron Toxicity Tolerance \\ Onny Chrisna Pandu Pradana*, Siti Novridha Andini}

${ }^{1}$ Politeknik Negeri Lampung, Jurusan Budidaya Tanaman Pangan

*E-mail: onnypradana@polinela.ac.id

\begin{abstract}
This research aimed to investigate the response of paddy culture (B7 strain) assembled by Lampung State Polytechnic to the iron toxicity tolerance. The research was done at Plant Tissue Culture Laboratory, Lampung State Polytechnic, from July to September 2019. Treatments were single arranged in a completely randomized design with three replications. The treatment tried was five levels of Fe concentrations (5,6 ppm $28 \mathrm{ppm}, 56 \mathrm{ppm}, 84 \mathrm{ppm}$, $112 \mathrm{ppm}$, and control). Each replication consisted of three culture bottles containing one explant. The homogeneity of data was tested using the Barlett test. If the assumption were fulfilled then analysis of variance is executed using STATISTICS 10, and then followed by the Honest Significant Difference (HSD) test in 5\% alpha for mean separation and RPA analysis. The result of this research showed that the B7 strain has tolerance to iron toxicity until 56 ppm of Fe concentration, it can be concluded from the PAR value of its strain $(>0,50)$. Meanwhile in 84 and 112 ppm of Fe concentration, the RPA value of B7 strain $(<0,50)$, and it is indicated that its strain is sensitive.
\end{abstract}

Keywords: paddy strain, in vitro, iron toxicity

Disubmit: 7 Oktober 2019; Diterima: 20 November 2019; Disetujui: 08 Desember 2019

\section{PENDAHULUAN}

Padi merupakan komoditas pangan utama di Indonesia dan merupakan bahan makanan pokok bagi sebagian besar masyarakat Indonesia. Saat ini, kebutuhan dalam negeri (kebutuhan nasional) akan bahan pokok ini sudah dapat terpenuhi. Menurut Kementrian Pertanian, (2018) produksi beras tahun 2016 sebesar 79,14 juta ton, sementara produksi pada tahun 2015 sebesar 70,85 juta ton, dari data tersebut menunjukkan adanya kenaikan sebesar $11,7 \%$. Apabila dikaitkan dengan jumlah penduduk Indonesia tahun 2017 yang berjumlah 262 juta jiwa, maka rata-rata konsumsi per kapita/tahun sebesar 114,6 kg/kapita/tahun. Kendati demikian, menurut Kementrian Pertanian, (2017) saat ini pemerintah masih terus mendorong upaya peningkatan produksi dan produktivitas padi, untuk meningkatkan nilai ekspor beras dan mencapai kedaulatan pangan, serta menuju lumbung pangan dunia di tahun 2045.

Salah satu upaya yang saat ini sedang digalakan pemerintah untuk meningkatkan produksi bahan pangan ini adalah dengan melakukan perluasan lahan tanam (ekstensifikasi pertanian). Saat ini ada 29 provinsi, dengan 284 kabupaten yang menjadi fokus kawasan sentra pangan strategis untuk komoditas padi (Kementrian Pertanian, 2017). Program ekstensifikasi ke daerah suboptimal, seperti lahan rawa pasang surut dan lahan masam akan menemui beberapa permasalahan dalam proses budidaya padi. Keracunan besi akan menjadi permasalah utama yang sering ditemui (Nugraha Y. dan I. A. Rumanti, 2017). Menurut Noor dan 
Khairuddin, (2013) pada tanah yang masam sampai sangat masam, memiliki kandungan unsur meracun Fe yang tinggi, serta kandungan dan ketersediaan haranya rendah.

Permasalahan ini dapat diatasi dengan penggunaan varietas padi yang bersifat adaptif pada $\mathrm{pH}$ tanah yang rendah dan toleran terhadap keracunan unsur Fe. Hal ini merupakan cara yang paling efektif dan ramah lingkungan. Varietas padi yang toleran dapat diperoleh melalui kegiatan pemuliaan tanaman, dimana dilakukan perakitan galur tanaman padi baru. Dari galur-galur yang dihasilkan, diharapkan ada galur yang memiliki karakteristik dapat berproduksi dengan baik walaupun ditanam pada kondisi tanah dengan $\mathrm{pH}$ yang rendah dan toleran terhadap keracunan unsur Fe. Menurut Syukur et al , (2012) tujuan utama dari program pemuliaan saat ini adalah merakit suatu varietas unggul yang memiliki produktivitas dan kualitas hasil lebih baik, serta memiliki ketahanan baik terhadap cekaman biotik maupun abiotik.

Untuk mengetahui apakah diantara galur-galur tersebut terdapat galur yang bersifat adaptif jika ditanaman pada tanah dengan tingkat keasaman tinggi dan toleran terhdapan keracunan unsur Fe, maka perlu dilakukan pengujian terhadap galur-galur tersebut dengan cara menanamnya pada tanah dengan berbagai tingkat keasaman dan tingkat konsentrasi unsur Fe. Akan tetapi, untuk mendapatkan tanah dengan karakteristik pH yang bervaraiasi cukup sulit, karena lokasi pengujian tidak saling berdekatan (cukup jauh), keterbatasan waktu yang dimiliki oleh peneliti, serta keterbatasan biaya. Selain itu keberadaan unsur-unsur lain di dalam tanah pada jumlah dan konsentrasi yang berbeda-beda juga akan menyulitkan peneliti dalam melakukan pengujian di lapang. Kondisi yang tidak homogen akan menyulitkan peneliti dalam mempelajari objek yang diteliti. Menurut Nugraha Y. dan I. A. Rumanti, (2017) penelitian keracunan besi di lapang sulit dikontrol karena kondisi lingkungan yang beragam, sehingga gejala keracunan besi pada varetas toleran tidak dapat dibedakan dengan yang peka. Hal ini akan menjadi permasalahan utama yang dihadapi dalam melakukan pengujian galur-galur tersebut.

Aplikasi teknik kultur jaringan dapat menjadi solusi dalam mengatasi permasalahan tersebut. Teknik kultur jaringan tanaman merupakan teknik menumbuh-kembangkan bagian tanaman, baik berupa sel, jaringan, atau organ dalam kondisi aseptik secara in vitro, yang dicirikan oleh kondisi kultur yang aseptik, media kultur buatan yang mengandung nutrisi lengkap, dan umumnya digunakan zat pengatur tumbuh, serta kondisi ruang kultur yang suhu dan pencahayaannya terkontrol (Yusnita, 2010). Teknik kultur jaringan tanaman memiliki peranan yang penting dalam produksi pertanian, produksi tanaman hias, dan rekayasa tanaman untuk perbaikan kualitas tanaman (Prasetyo, et al, 2014)Pada teknik ini, pH media tumbuh dan juga konsentrasi unsur-unsur yang dibutuhkan oleh tanaman dapat dikontrol sesuai dengan kebutuhan tanaman ataupun kebutuhan peneliti. Sebelumnya, pengujian secara in vitro terhadap galur padi rakitan Politeknik Negeri Lampung pada kondisi cekaman pH telah dilakukan oleh Pradana, et al, (2018) dari hasil penelitian tersebut dilaporkan bahwa galur padi B7 menunjukan sifat yang toleran terhadap cekaman $\mathrm{pH}$, namum hanya sampai pada batas $\mathrm{pH}$ 4. Sampai saat ini belum diketahui bagaimana respons galur-galur tersebut terhadap keracunan unsur Fe pada kondisi $\mathrm{pH}$ rendah. Penelitian ini bertujuan untuk mengetahui respons galur tanaman padi rakitan Politeknik Negeri Lampung terhadap keracunan unsur besi ( $\mathrm{Fe}$ ) dan mendapatkan galur tanaman padi yang berpotensi memiliki sifat toleran terhadap keracunan unsur besi (Fe) pada kondisi $\mathrm{pH}$ rendah.

\section{METODE PENELITIAN}

Penelitian dilaksanakan di Laboratorium Kultur Jaringan Tanaman, Politeknik Negeri Lampung, pada bulan Mei sampai dengan Agustus 2019. Bahan-bahan yang dibutuhkan pada penelitian ini antara lain bahan tanam (eksplan) yang berasal dari biji tanaman padi, formulasi media yang digunakan untuk perlakuan adalah media MS yang ditambahkan BA dengan konsentrasi $5 \mathrm{mg} / \mathrm{l}$. Penggunaan BA dengan konsentrasi 5 mg/l pada media MS untuk kultur jaringan tanaman padi, menunjukkan hasil yang terbaik bagi pertumbuhan kultur (Sankepally, 2016). Bahan-bahan pendukung lain yang digunakan antara lain, deterjen, Dithane M-45 
Pradana, $O, C, P ., \&$ Andini, S, N. : In Vitro Screening Ketahanan Galur Padi (Oryza sativa) B7 Hasil

(2 g/l), amoxilyn, air akuades dan steril, Bayclin $30 \%$ dan 15\%, Tween 20, KOH $1 \mathrm{~N}, \mathrm{HCl} 1 \mathrm{~N}$, spiritus, kertas, agar-agar, gula, dan kertas label.

Alat-alat yang digunakan pada tahap persiapan dan pembuatan media antara lain timbangan, neraca analitik, botol kultur, labu takar, labu erlenmeyer, pipet tetes, gelas piala, gelas ukur, spatula, sendok spatula, $\mathrm{pH}$ meter, kompor, autoclave, panci, destilator, botol aquades, botol scott, alat tulis, dan magnetic stirrer. Sementara, alat-alat yang digunakan pada tahap penanaman, antara lain laminar air flow cabinet (LAFC), cawan petri, lampu bunsen, hand sprayer, shaker dan alat-alat diseksi (scalpel, surgical blade, pinset).

Pada penelitian ini rancangan perlakuan disusun secara tunggal. Perlakuan diterapkan pada satuan percobaan dalam rancangan acak lengkap (completely randomized design). Setiap perlakuan diulang tiga kali dan setiap ulangan terdiri dari tiga botol kultur yang masing-masing berisi satu eksplan. Perlakuan yang dicobakan adalah dua galur tanaman padi rakitan Politeknik Negeri Lampung, yaitu galur B7 dan F4 yang dikombinasikan dengan lima konsentrasi Fe (5,6 ppm; 28 ppm; 56 ppm; 84 ppm; 112 ppm; dan kontrol). Nilai tengah untuk masing-masing variabel pada setiap perlakuan dihitung dari tiga ulangan. Dalam penelitian ini, keseragaman data diuji dengan menggunakan Uji Barlett. Jika asumsi terpenuhi, dilakukan analisis ragam dengan menggunakan software STATISTIX, kemudian dilanjutkan dengan uji BNJ pada taraf 5\% untuk pemisahan nilai tengahnya, serta menghitung nilai Relatif Panjang Akar (RPA), yaitu perbandingan antara panjang akar pada kondisi cekaman dengan panjang akar pada kondisi normal (kontrol) (Umaiyah, 2016). Kriteria galur toleransi terhadap cekaman apabila memiliki nilai Relatif Panjang Akar $($ RPA $)>0,50$ (Suhartini, 2010)

\section{HASIL DAN PEMBAHASAN}

Kondisi Umum Kultur. Kultur mulai menunjukkan gejala pertumbuhan pada umur 3 HST di media perlakuan, hal ini ditandai dengan adanya pembengkakan berwarna putih pada bagian eksplan yang selanjutnya akan tumbuh dan berkembang menjadi tunas. Pembengkakan berwarna putih ini akan mulai terlihat jelas pada saat kultur berumur 5 HST dan pada umur 7 HST tunas yang tumbuh sudah dapat terlihat dengan jelas pada kultur. Penampilan visual kultur padi Galur B7 disajikan pada Gambar 1.

Kendala yang dihadapi pada kultur padi ini adalah kontaminasi yang disebabkan oleh jamur dan bakteri. Jamur dan bakteri yang muncul pada kultur dapat menghambat pertumbuhan kultur dan bahkan dapat mengakibatkan kematian pada eksplan yang dikulturkan. Pada kultur padi ini, pengamatan akhir dilakukan pada saat kultur berumur 28 HST, dimana pertumbuhan dan perkembangan tunas dan akar sudah sempurna.

Rekapitulasi Analisis Data. Penelitian yang telah dilakukan diperoleh hasil bahwa galur padi B7 memberikan respon pertumbuhan yang berbeda-beda pada setiap taraf konsentrasi $\mathrm{Fe}$ yang diujikan. Rekapitulasi hasil analisis data pertumbuhan kultur padi galur B7 disajikan pada Tabel 1.

Tabel 1. Rekapitulasi Hasil Analisis Ragam untuk Galur Padi B7

\begin{tabular}{lll}
\hline Variabel Pengamatan & Perlakuan (Konsentrasi Fe) & KK $(\%)$ \\
\hline Rerata Jumlah Tunas & tn & 21,7 \\
Rerata Panjang Tunas & $*$ & 3,2 \\
Rerata Jumlah Akar & $*$ & 12,9 \\
Rerata Panjang Akar & $*$ & 14,1 \\
Rerata Jumlah Daun & $*$ & 13,6
\end{tabular}

Keterangan: $(*)=$ signifikan/berbeda nyata pada taraf $\alpha$ 5\%

$(\mathrm{ns})=$ non-signifikan/tidak berbeda nyata pada taraf $\alpha 5 \%$ 

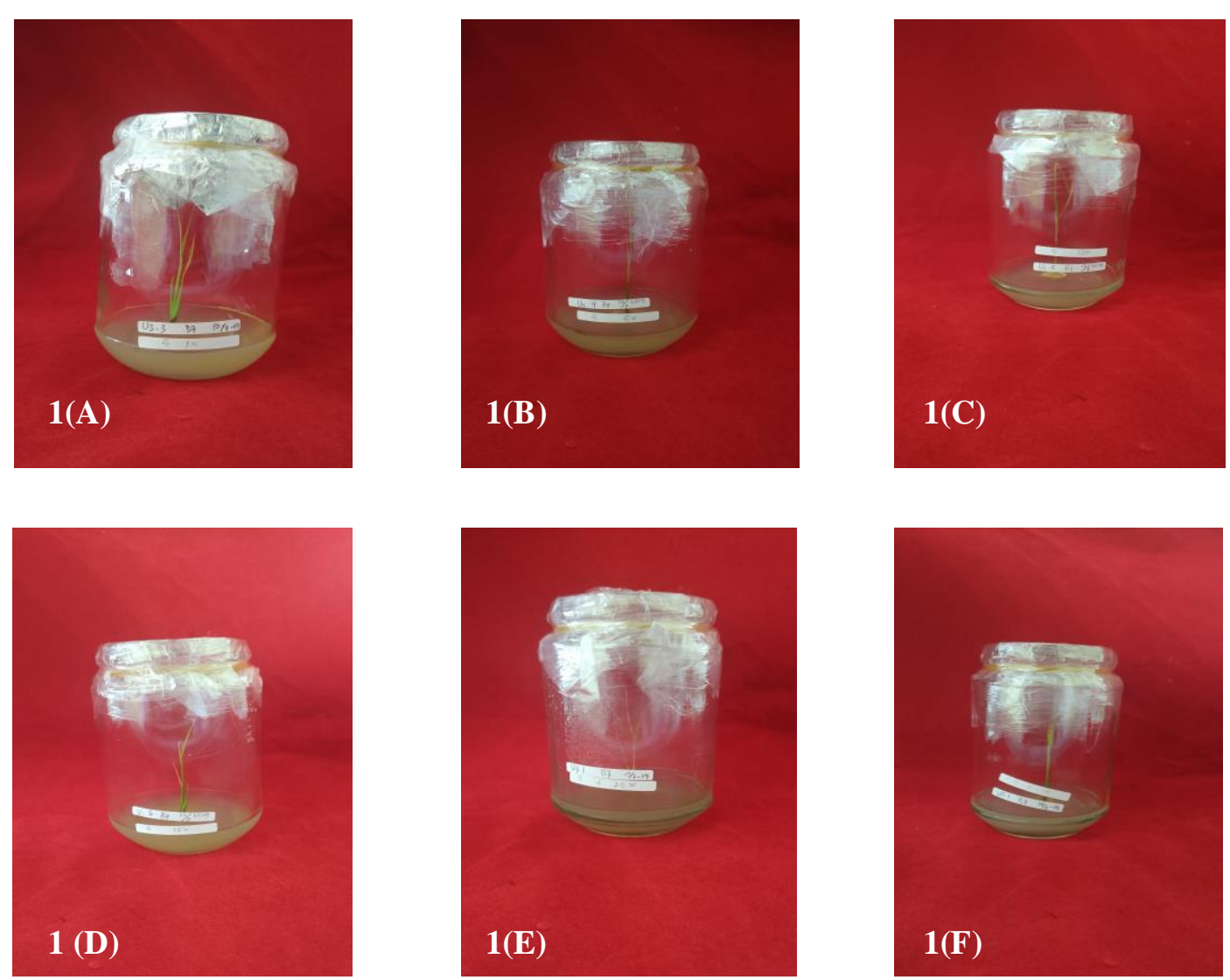

Gambar 1. Kultur padi galur B7 umur 28 HST pada kondisi: (A) pH media $5+$ Konsentrasi Fe 5,6 ppm; (B) pH media 5 + Konsentrasi Fe 28 ppm; (C) pH media 5 + Konsentrasi Fe 56 ppm; (D) pH media $5+$ Konsentrasi Fe 84 ppm; (E) pH media 5 + Konsentrasi Fe 112 ppm; (F) pH media 5,8 + Konsentrasi Fe 5,6 ppm

Tabel 2. Rekapitulasi Hasil Uji BNJ (5\%) untuk Galur Padi B7

\begin{tabular}{lllllll}
\hline No & Perlakuan & RJT & RPT & RJA & RPA & RJD \\
\hline 1 & pH 5 + Fe 1x (5,6 ppm) & $1,18 \mathrm{a}$ & $9,40 \mathrm{a}$ & $2,50 \mathrm{a}$ & $2,50 \mathrm{a}$ & $3,20 \mathrm{~b}$ \\
2 & pH 5 + Fe 5x (28 ppm) & $1,08 \mathrm{a}$ & $9,07 \mathrm{a}$ & $2,37 \mathrm{a}$ & $1,73 \mathrm{~b}$ & $3,90 \mathrm{ab}$ \\
3 & pH 5 + Fe 10x (56 ppm) & $1,00 \mathrm{a}$ & $8,07 \mathrm{~b}$ & $2,37 \mathrm{a}$ & $1,67 \mathrm{~b}$ & $3,80 \mathrm{ab}$ \\
4 & pH 5 + Fe 15x (84 ppm) & $1,14 \mathrm{a}$ & $7,30 \mathrm{c}$ & $2,27 \mathrm{a}$ & $1,13 \mathrm{bc}$ & $4,33 \mathrm{ab}$ \\
5 & pH 5 + Fe 20x (112 ppm) & $1,13 \mathrm{a}$ & $6,33 \mathrm{~d}$ & $1,00 \mathrm{~b}$ & $0,87 \mathrm{c}$ & $4,93 \mathrm{a}$ \\
6 & pH 5,8 + Fe 1x (5,6 ppm) & $1,44 \mathrm{a}$ & $9,27 \mathrm{a}$ & $2,40 \mathrm{a}$ & $2,67 \mathrm{a}$ & $3,20 \mathrm{~b}$ \\
\hline \multicolumn{2}{l}{ Nilai BNJ } & - & 0,72 & 0,76 & 0,68 & 1,45 \\
\hline
\end{tabular}

Keterangan: Angka yang diikuti oleh huruf yang sama pada kolom yang sama menunjukan tidak berbeda nyata pada uji BNJ pada $\alpha$ 5\%; RJT= Rerata Jumlah Tunas ; RPT = Rerata Panjang Tunas; RJA= Rerata Jumlah Akar; RPA = Rerata Panjang Akar; RJD= Rerata Jumlah Daun

Tabel 2 menunjukkan bahwa dari keenam taraf konsentrasi Fe yang diujikan, minimal terdapat satu taraf konsentrasi Fe yang memberikan pengaruh yang berbeda nyata pada panjang tunas, jumlah akar, panjang akar, dan jumlah daun. Sementara pada variabel jumlah tunas, perlakuan konsentrasi Fe yang diujikan memberikan pengaruh yang tidak berbeda nyata. Selanjutnya dilakukan uji BNJ untuk mengetahui perbedaan nilai tengah antar perlakuan. 
Pradana, O, C, P., \& Andini, S, N. : In Vitro Screening Ketahanan Galur Padi (Oryza sativa) B7 Hasil

Rerata Jumlah Tunas. Pada penelitian ini rerata jumlah tunas yang dihasilkan oleh galur padi B7 pada berbagai taraf konsentrasi Fe yang diujikan memberikan hasil yang tidak berbeda nyata (Gambar 2). Artinya galur padi B7 memberikan respons pertumbuhan jumlah tunas yang sama pada semua taraf konsentrasi Fe. Hasil ini sejalan dengan hasil penelitian Pradana, et al, (2018) pada penelitian tersebut galur padi $\mathrm{B} 7$ menghasilkan rerata jumlah tunas yang sama pada berbagai taraf cekaman $\mathrm{pH}$ yang diujikan $(\mathrm{pH}$ $3,5-5,8)$.

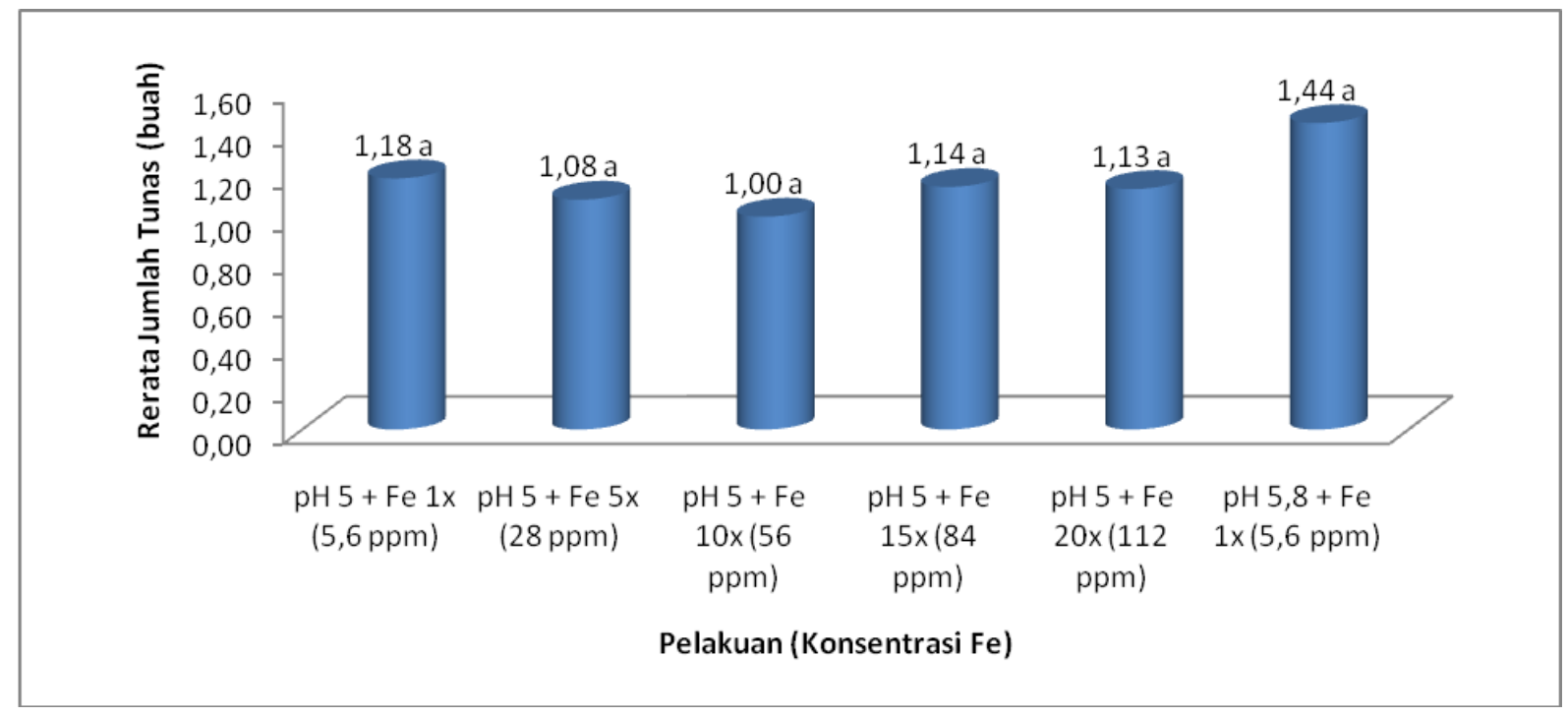

Gambar 2. Rerata jumlah tunas (buah)

Rerata Panjang Tunas. Rerata panjang tunas yang dihasilkan oleh galur padi B7 menunjukkan hasil berbeda nyata dari konsentrasi Fe yang diujikan (Gambar 3). Rerata panjang tunas terendah diperoleh pada perlakuan konsentrasi Fe $112 \mathrm{ppm}$, yaitu $6,33 \mathrm{~cm}$ dan nilai ini berbeda nyata dengan perlakuan yang lainnya. Sementara rerata panjang tunas tertinggi diperoleh pada perlakuan konsentrasi Fe 5,6 ppm, 28 ppm, dan kontrol $(5,6 \mathrm{ppm}$ Fe pada $\mathrm{pH}$ 5,8). Artinya galur padi B7 memberikan respons pertumbuhan panjang tunas yang sama baiknya pada ketiga taraf konsentrasi tersebut.

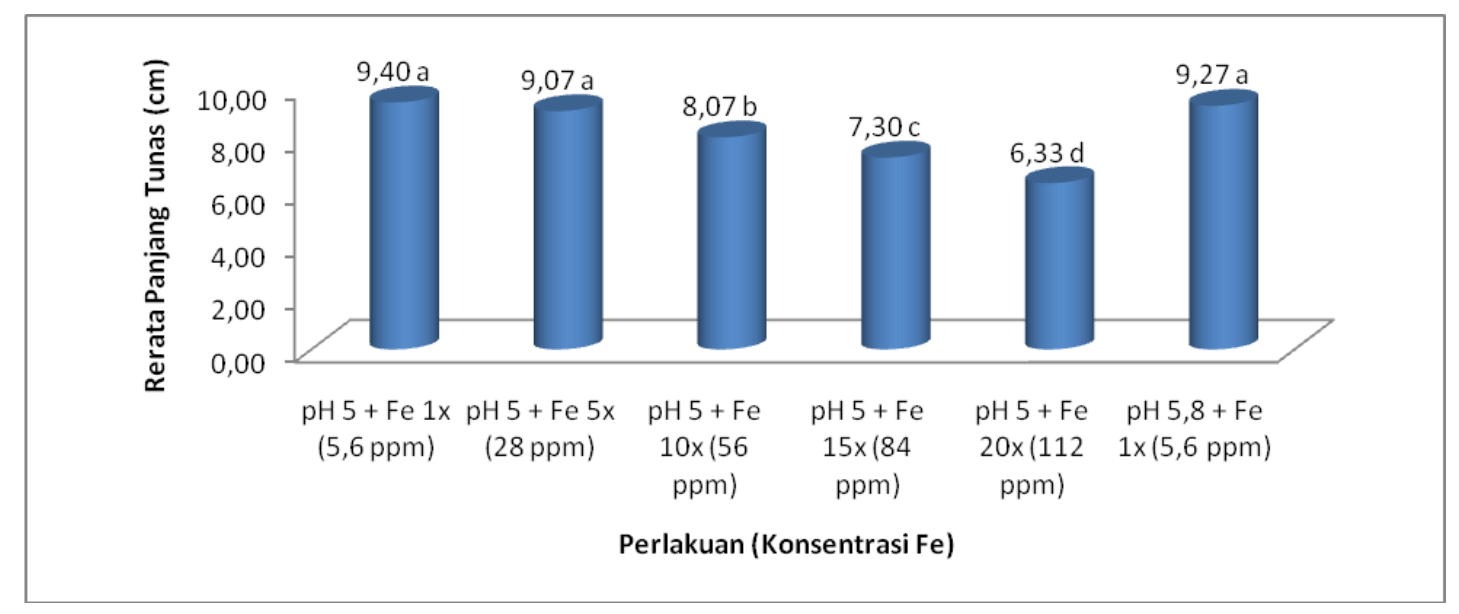

Gambar 3. Rerata panjang tunas $(\mathrm{cm})$

Secara umum dapat dikatakan bahawa rerata panjang tunas yang dihasilkan akan menurun seiring dengan meningkatnya konsentrasi Fe di media kultur. Pradana, et al (2018), juga melaporkan hal yang 
serupa. Rerata panjang tunas yang dihasilkan oleh galur B7 akan menurun seiring menururunya pH media tumbuh. Salam. A.K., (2012) menyatakan bahawa terdapat hubungan yang erat antara $\mathrm{pH}$ tanah dengan konsentrasi Fe di dalam tanah. Ketersediaan unsur hara mikro kelompok logam seperti $\mathrm{Fe}, \mathrm{Mn}, \mathrm{Zn}$, dan $\mathrm{Cu}$ akan menurun dengan meningkatnya $\mathrm{pH}$ tanah, begitu pula sebaliknya.

Rerata Jumlah Daun. Rerata jumlah daun yang dihasilkan oleh galur padi B7 menunjukkan hasil yang berbeda nyata pad setiap taraf konsentrasi Fe yang diujikan (Gambar 4). Rerata jumlah daun terendah diperoleh pada perlakuan konsentrasi Fe 5,6 ppm dan kontrol (5,6 ppm Fe pada pH 5,8) yaitu sebanyak 3,20 helai. Rerata jumlah daun tertinggi diperoleh pada perlakuan konsentrasi Fe 112 ppm, sebanya 4,93 helai.

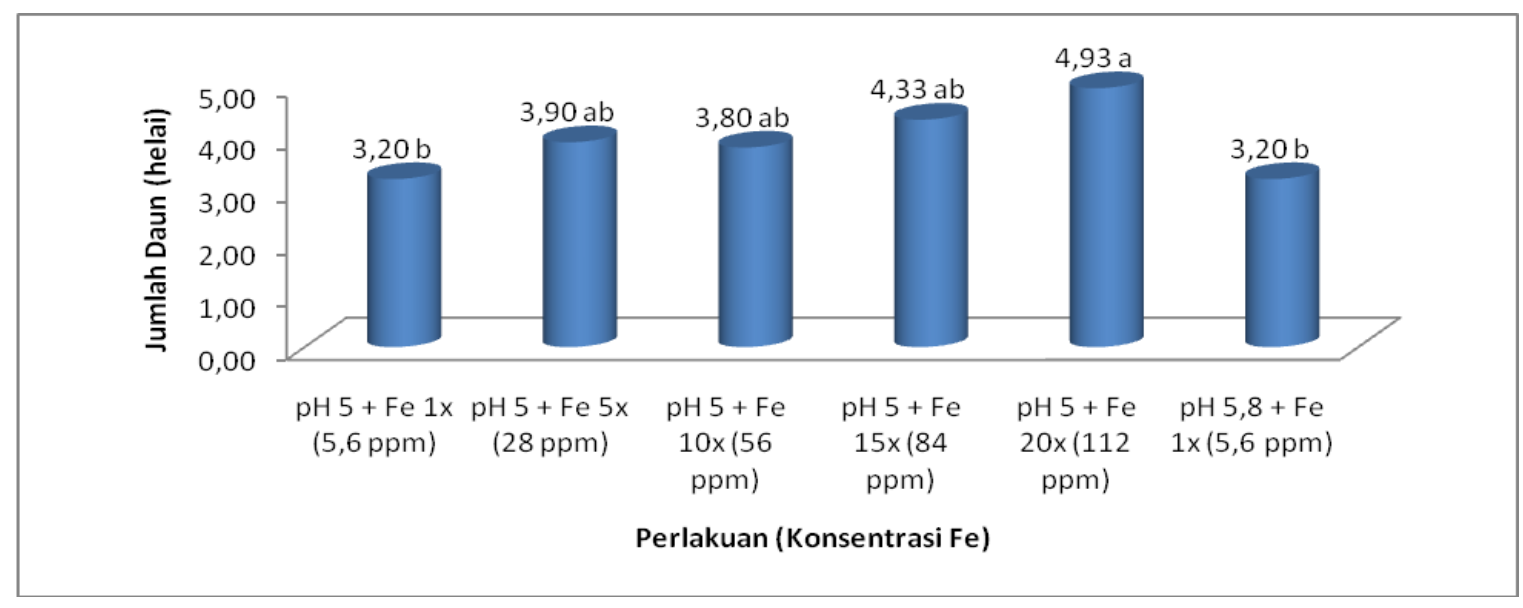

Gambar 4. Rerata jumlah daun (helai)

Rerata Jumlah Akar Pada penelitian ini, dapat diketahui bahwa terdapat perbedaan yang nyata pada rerata jumlah akar yang dihasilkan oleh galur padi B7 (gambar 5). Rerata jumlah akar terendah diperoleh pada perlakuan konsentrasi Fe 112 ppm, yaitu 1,00 dan nilai ini berbeda nyata dengan perlakuan yang lainnya. Rerata panjang tunas yang dihasilkan pada perlakuan konsentrasi Fe 5,6 ppm, 28 ppm, 56 ppm, 84 ppm, serta kontrol $(5,6$ ppm Fe pada pH 5,8) menunjukan hasil yang tidak berbeda nyata $(2,50 ; 2,37 ; 2,37$; 2,27; dan 2,40).

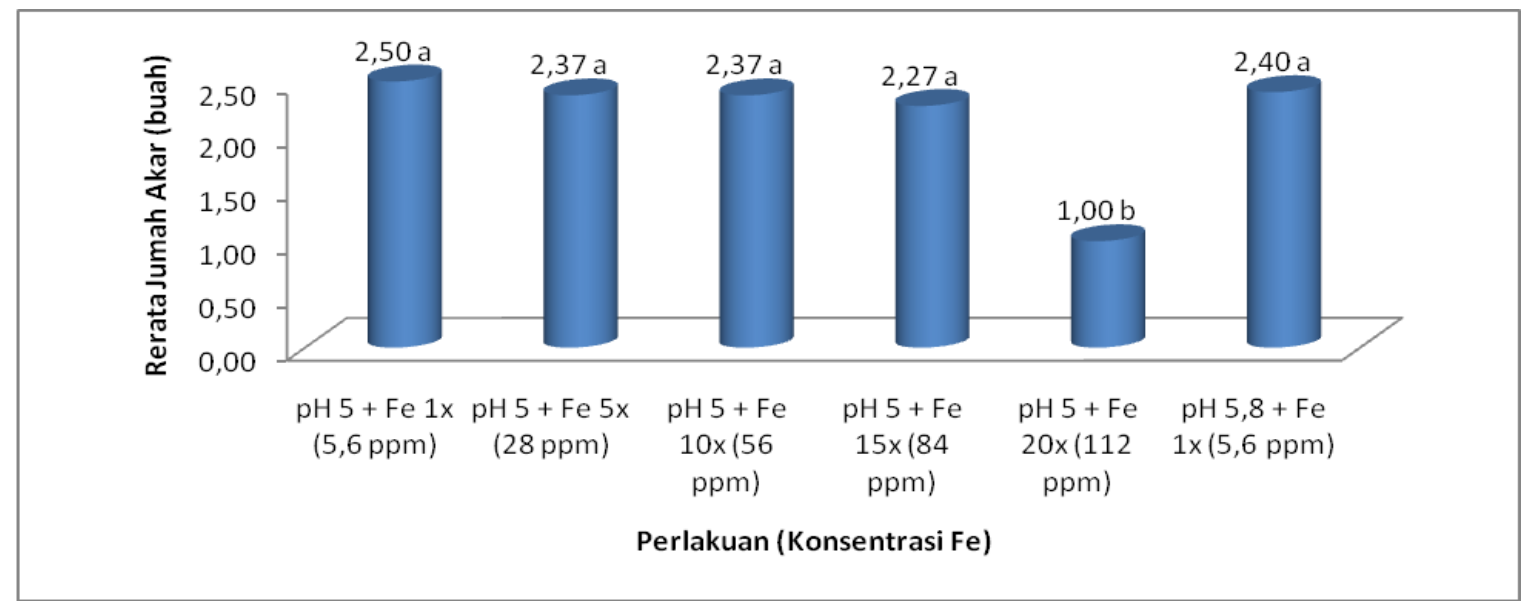

Gambar 5. Rerata jumlah akar (buah)

Berdasarkan hasil yang diperoleh, dapat dikatakan bahwa galur padi B7 memberikan respons pertumbuhan jumlah akar yang sama baiknya pada konsentrasi Fe 5,6-84 ppm. Hal ini mengindikasikan 
Pradana, O, C, P., \& Andini, S, N. : In Vitro Screening Ketahanan Galur Padi (Oryza sativa) B7 Hasil

bahwa galur padi B7 memiliki sifat toleran terhadap keracunan unsur Fe. Konsentrasi Fe yang tinggi pada tanah masam ( $\mathrm{pH}$ rendah) dapat berpengaruh negatif terhadap pertumbuhan tanaman.

Rerata Panjang Akar. Pada variabel rerata panjang akar, diperoleh hasil yang berbeda nyata pada taraf konsentrasi Fe yang diujikan. Rerata panjang akar terendah diperoleh pada perlakuan konsentrasi $\mathrm{Fe}$ $112 \mathrm{ppm}$, yaitu sebesar $0,87 \mathrm{~cm}$ dan nilai ini berbeda nyata dengan perlakuan yang lainnya. Rerata panjang akar tertinggi diperoleh pada perlakuan konsentrasi Fe 5,6 ppm dan kontrol $(5,6 \mathrm{ppm}$ Fe pada pH 5,8) yaitu sebesar 2,50 dan 2,67 cm (Gambar 6).

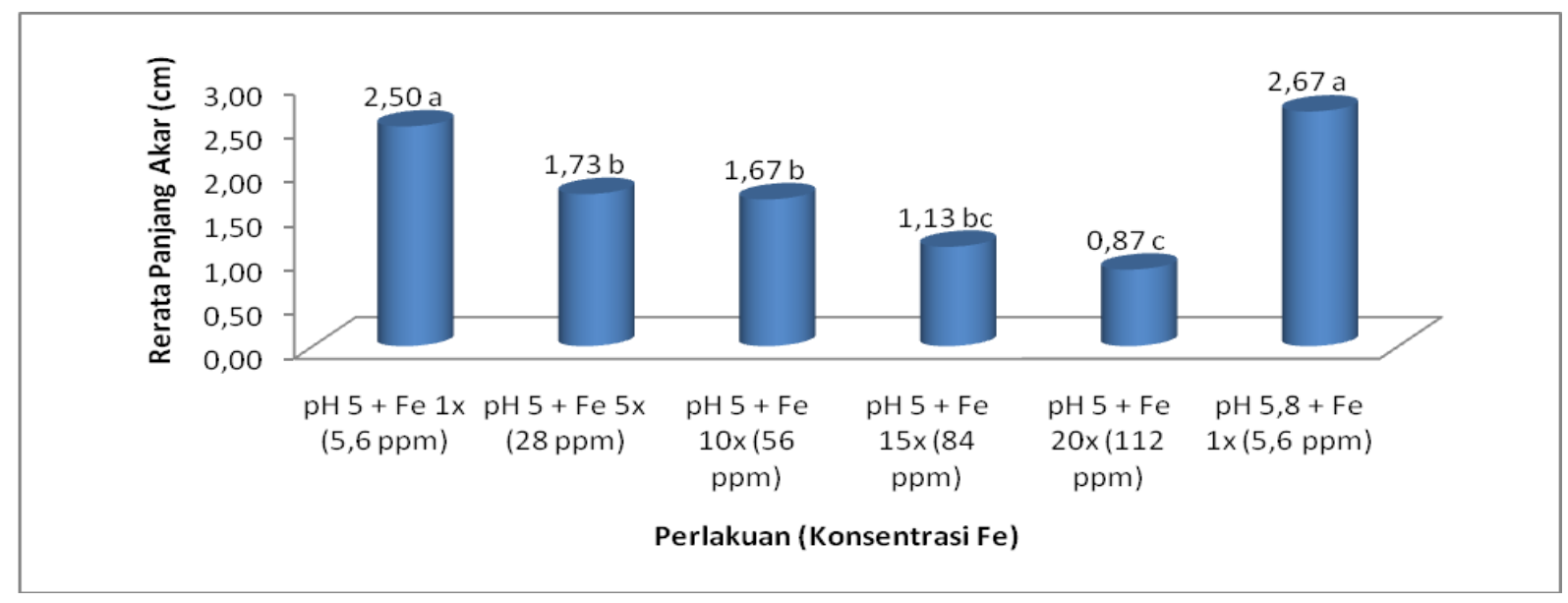

Gambar 6. Rerata panjang akar (cm)

Pada penelitian ini, juga dilakukan analisis terhadap nilai Relatif Panjang Akar (RPA) untuk menentukan apakah galur yang diuji bersifat toleran atau peka. Hasil analisis RPA disajikan pada Tabel 3.

Tabel 3. Hasil Analisis RPA untuk Galur Padi B7

\begin{tabular}{llll}
\hline No & Perlakuan (Konsentrasi Fe) & Nilai PAR & Keterangan \\
\hline 1 & pH 5 + Fe 1x (5,6 ppm) & 0,94 & Toleran \\
2 & pH 5 + Fe 5x (28 ppm) & 0,64 & Toleran \\
3 & pH 5 + Fe 10x (56 ppm) & 0,63 & Toleran \\
\hline 4 & pH 5 + Fe 15x (84 ppm) & 0,43 & Peka \\
5 & pH 5 + Fe 20x (112 ppm) & 0,32 & Peka \\
\hline
\end{tabular}

Berdasarkan hasil analisis nilai RPA, dapat diketahui bahwa secara umum kultur padi galur B7 menunjukan sifat toleran terhadap keracunan unsur Fe (RPA > 0,50), namun hanya sampai pada batas kosentrasi Fe 56 ppm. Sementara pada konsentrasi Fe 84 dan 112 ppm, galur ini menunjukan sifat peka, yang terlihat dari nilai RPA 0,43 dan 0,32 $(<0,50)$. Suhartini (2010), melaporkan bahwa dalam pengujian genotipe padi pada kondisi kahat fosfor dan cekaman alumunium, galur tersebut dikatakan toleran apabila memiliki nipa RPA > 0,50. Berdasarkan pengelompokan tersebut, maka dapat dikatakan bahwa galur padi B7 memiliki sifat toleran terhadap keracunan Fe.

\section{KESIMPULAN}

Galur B7 memiliki sifat toleran terhadap keracunan unsur Fe sampai batas konsentrasi Fe 56 ppm, hal ini dapat dilihat dari nilai PAR galur tersebut $(>0,50)$. 


\section{UCAPAN TERIMA KASIH}

Terima kasih penulis ucapkan kepada Ir. Jaenudin Kartahadimaja, M.P. yang telah menyediakan dan mengizinkan penulis untuk menggunakan benih padi galur B7 sebagai sumber eksplan dalam penelitian ini, dan kepada Politeknik Negeri Lampung sebagai penyandang dana dalam penelitian ini melalui program Hibah Kompetitif Penelitian DIPA POLINELA 2019 Nomor Kontrak: 066.56/PL 15.8/PP/2019 tanggal 29 Maret 2019.

\section{DAFTAR PUSTAKA}

Kementrian Pertanian (2017) Kedaulatan pangan nasional. Jakarta: www.kementan.go.id. Diakses tanggal 15 Februari 2019.

Kementrian Pertanian (2018) Data kementan selaras dengan data BPS. Jakarta: . www. kementan.go.id. Diakses tanggal 15 Februari 2019.

Noor, A. and Khairuddin (2013) 'Keracunan Besi Pada Padi: Aspek Ekologi Dan Fisiologi-Agronomi', Prosiding Seminar nasional inovasi pertanian.

Nugraha Y. dan I. A. Rumanti (2017) 'Perakitan Varietas Padi Toleran Keracunan Besi', Iptek Tanaman Pangan, 12 (1):., p. 9-24.

Pradana, O. C. P., S. N. Andini, and W. R. (2018) 'In Vitro Screening of B7 Paddy (Oryza sativa) Strain For pH Stress Tolerance', in Prosiding Seminar Nasional Teknologi Pertanian VII. Bandar Lampung: Politeknik Negeri Lampung.

Prasetyo, A., Utomo, W. H. and Listyorini, E. (2014) 'Hubungan Sifat Fisik Tanah, Perakaran dan Hasil Ubi Kayu Tahun Kedua pada Alfisol Jatikerto akibat pemberian Pupuk Organik dan Anorganik', Jurnal Tanah dan Sumber Daya Lahan.

Salam. A.K. (2012) Ilmuh Tanah Fundamental. Global Madani Press. Bandar Lampung. 362.

Sankepally, S. S. R. dan B. S. (2016) 'Optimization of regeneration using differential growth regulators in indica rice cultivars', 3 Biotech, 6 (19): 1-.

Suhartini, T. (2010) 'Pertumbuhan Akar Dua Puluh Genotipe Padi Gogo pada Kahat Fosfor dan Cekaman Alumunium', Berita Biologi, 10 (3): 37.

Syukur, M., S. Sujiprihati, dan R. Y. (2012) Teknik Pemuliaan Tanaman. Jakarta: Penebar Swadaya. Jakarta.

Umaiyah, E. I. (2016) 'Respon Fisiologi, Morfologi, dan Anatomi Akar Padi Hawara Bunar Transgenik yang Mengalami Pembungkaman Gen B11 terhadap Cekaman pH Rendah dan Alumunium. (Skripsi)', Institut Pertanian Bogor.

Yusnita (2010) 'Perbanyakan In Vitro Tanaman Anggrek.Universitas Lampung. Bandar Lampung. 128 hlm.' 